\title{
Bovine Mycoplasmas: Genome Size and Base Composition of DNA
}

\author{
By GERD ASKAA, C. CHRISTIANSEN AND H. ERNØ \\ Institute of Medical Microbiology, University of Aarhus, Aarhus, Denmark
}

(Received 7 August 1972 ; revised 19 October 1972)

\begin{abstract}
SUMMAR Y
Within the order Mycoplasmatales guanine plus cytosine contents and genome sizes have been determined for 17 strains representing 15 bovine and two ovine species, subspecies or serogroups. The guanine plus cytosine contents were found to vary between 24.4 and $32.9 \%$. The genome sizes were 4.0 to $5.6 \times 10^{8}$ daltons for I 4 sterol-requiring strains and 0.99 to $\mathrm{I} \cdot \mathrm{I} \times \mathrm{IO}^{9}$ daltons for three non-sterol-requiring strains. These results support earlier findings that members of the genus Acholeplasma (family Acholeplasmataceae) have genome sizes about twice those of the genus Mycoplasma (family Mycoplasmataceae).
\end{abstract}

\section{INTRODUCTION}

Determination of the mean guanine plus cytosine (GC) contents of mycoplasmal DNA has shown that mycoplasmas form a rather heterogeneous group with variations from 23 to $40 \%$ (Neimark, 1970). Studies by Bak, Black, Christiansen \& Freundt (I969) suggest that the sterol-requiring genus Mycoplasma (family Mycoplasmataceae) and the non-sterolrequiring genus Acholeplasma (family Acholeplasmataceae, Edward \& Freundt, 1970) are also different in regard to their genome sizes. The Mycoplasma species tested have genome sizes within the range of 4 to $5 \times 10^{8}$ daltons, whereas those of the Acholeplasma species are about $\mathrm{I} \cdot \mathrm{O} \times 1 \mathrm{IO}^{9}$ daltons.

The purpose of this work was to determine the GC contents and the genome sizes of type or reference strains of all known mycoplasma species, subspecies and serogroups of bovine source. The type strains (PG2 and PG3) of two ovine organisms (Mycoplasma agalactiae subsp. agalactiae and $M$. mycoides subsp. capri) were included in the study because of serological relatedness to the bovine strains (M. agalactiae subsp. bovis (Donetta) and $M$. mycoides subsp. mycoides (PGI), respectively).

\section{METHODS}

The mycoplasmas investigated (Table I) were obtained from Drs D. G. FF. Edward, J. Fabricant and E. A. Freundt and from the National Collection of Type Cultures, Colindale, London (Ernø \& Stipkovits, 1973).

The substrates used for cultivation were in most cases Bacto Heart Infusion Broth (Difco), supplemented with $15 \%$ horse serum or I \% PPLO Serum Fraction, $8 \%$ fresh yeast extract, $0.003 \%$ phenol red, $0.08 \%$ thallium acetate and penicillin (400 i.u. $/ \mathrm{ml}$ ). Some strains were also supplied with $0.8 \%$ glucose (PG49, PG50, BI07PA, PG I, PG3) or I \% arginine (B I39P, BI 42P, G230).

Mycoplasma dispar was cultivated in FF II medium (Friis, 1972), with minor modifications; it comprised Bacto Brain Heart Infusion Broth (Difco, Detroit, Michigan, U.S.A.), 
Table I. Melting temperatures, base compositions and genome sizes of DNA from fifteen bovine and two ovine mycoplasma species

\begin{tabular}{|c|c|c|c|c|}
\hline $\begin{array}{l}\text { Species or } \\
\text { serogroup }\end{array}$ & $\begin{array}{l}\text { Type or } \\
\text { reference } \\
\text { strain }\end{array}$ & $\begin{array}{c}\text { Melting } \\
\text { temperature* } \\
\left({ }^{\circ} \mathrm{C}\right)\end{array}$ & $\begin{array}{c}\text { Base com- } \\
\text { position } \\
(\% \mathrm{GC})\end{array}$ & $\begin{array}{l}\text { Genome size* } \\
\text { (10 }{ }^{8} \text { daltons) }\end{array}$ \\
\hline Mycoplasma dispar & $462 / 2$ & $8 I \cdot 3 \pm 0.05(4)$ & $29 \cdot 3$ & $5 \cdot 3 \pm 0 \cdot 4(3)$ \\
\hline M. bovirhinis & PG 43 & $80.5 \pm 0.15(6)$ & $27 \cdot 3$ & $4.4 \pm 0.2(3)$ \\
\hline $\begin{array}{l}\text { M. mycoides subsp. } \\
\text { mycoides }\end{array}$ & PG I & $80 \cdot 4 \pm 0 \cdot 10(9)$ & $27 \cdot I$ & $5 \cdot 0 \pm 0 \cdot 1(3)$ \\
\hline M. mycoides subsp. capri & PG 3 & $79 \cdot 3 \pm 0 \cdot 00(4)$ & $24 \cdot 4$ & $5 \cdot 0 \pm 0.3(5)$ \\
\hline Group L (Al-Aubaidi) & B 144P & $79 \cdot 7 \pm 0.15(6)$ & $25 \cdot 4$ & $4.9 \pm 0.4(5)$ \\
\hline Group 7 (Leach) & PG50 & $79 \cdot 7 \pm 0.05(4)$ & $25 \cdot 4$ & $5 \cdot 6 \pm 0 \cdot 2(6)$ \\
\hline M. bovigenitalium & PGI I & $8 \mathrm{I} \cdot 7 \pm 0.05(4)$ & $30 \cdot 2$ & $4 \cdot 0 \pm 0.3(4)$ \\
\hline $\begin{array}{l}\text { M. agalactiae subsp. } \\
\text { agalactiae }\end{array}$ & PG 2 & $81 \cdot 8 \pm 0 \cdot 10(5)$ & $30 \cdot 5$ & $4 \cdot 7 \pm 0 \cdot 3(3)$ \\
\hline $\begin{array}{l}\text { M. agalactiae subsp. } \\
\text { bovis }\end{array}$ & Donetta & $80 \cdot 7 \pm 0.05(7)$ & $27 \cdot 8$ & $4 \cdot 4 \pm 0.1(2)$ \\
\hline M. arginini & G230 & $80 \cdot 6 \pm 0 \cdot 15$ (4) & $27 \cdot 6$ & $4 \cdot 0 \pm 0 \cdot 3(6)$ \\
\hline Group 8 (Leach) & PG5 I & $79 \cdot 9 \pm 0 \cdot 10(4)$ & $25 \cdot 9$ & $4.9 \pm 0.3(5)$ \\
\hline Group H (Al-Aubaidi) & BI39P & $79 \cdot 8 \pm 0 \cdot 10(5)$ & $25 \cdot 6$ & $4.4 \pm 0.4(3)$ \\
\hline Group I (Al-Aubaidi) & $\mathrm{B} I 42 \mathrm{P}$ & $80 \cdot 6 \pm 0.05(4)$ & $27 \cdot 6$ & $4 \cdot 8 \pm 0.1(2)$ \\
\hline Unclassified & MI65/69† & $81 \cdot 2 \pm 0 \cdot 10(2)$ & $29 \cdot 0$ & $4 \cdot 3 \pm 0.3(2)$ \\
\hline Acholeplasma laidlawii & PG8 & $82 \cdot 8 \pm 0 \cdot 20(12)$ & $32 \cdot 9$ & $110 \div$ \\
\hline Group 6 (Leach) & PG49 & $8 \mathrm{I} \cdot 3 \pm 0 \cdot 15(5)$ & $29 \cdot 3$ & $9 \cdot 9 \pm I \cdot 3(4)$ \\
\hline Group K (Al-Aubaidi) & BIO7PA & $8 \mathrm{I} \cdot 4 \pm 0.10(4)$ & $29 \cdot 5$ & $9.9 \pm 0.8(5)$ \\
\hline
\end{tabular}

* Measured values and standard deviations. Number of determinations are given in parentheses.

$\uparrow$ Isolated by Langford \& Dorward (I969).

\$ Previously reported (Bak et al. 1969).

I0 \% horse serum, 10 \% SPF pig serum, $0.05 \%$ yeast extract (Difco), I \% fresh yeast extract, $0.125 \%$ lactalbumine hydrolysate (Difco), $0.5 \%$ Bacto PPLO broth (Difco) and $0.1 \%$ glucose in Hanks's balanced salt solution and double-distilled water. Phenol red (0.002\%), thallium acetate $(0.009 \%)$ and bacitracin $(0.02 \%)$ were also added.

Cultures were obtained by inoculation of $50 \mathrm{ml}$ of broth with $0.1 \mathrm{ml}$ stock culture (derived from a single colony, containing about $10^{8}$ organisms $/ \mathrm{ml}$ and stored at $-70^{\circ} \mathrm{C}$ ). After incubation at $37^{\circ} \mathrm{C}$ for at least $24 \mathrm{~h} 5000 \mathrm{ml}$ of substrate were inoculated with this preculture and harvested in the late $\log$ phase in the Sorvall continuous flow system at $48000 \mathrm{~g}$, flow rate $20 \mathrm{ml} / \mathrm{min}$. The DNA was isolated according to Marmur (I96I) with the modifications described by Bak \& Stenderup (1969). Melting-point determinations were made by measuring extinction of DNA in I $\times \mathrm{SSC}(0.15 \mathrm{M}-\mathrm{NaCl}$ and $0.0 \mathrm{I} 5 \mathrm{M}$-trisodium citrate) under controlled temperature increase $\left(0.25^{\circ} \mathrm{C} / \mathrm{min}\right)$ in a Unicam SP800 spectrophotometer equipped with an SP 876 temperature programme controller and an $\mathrm{X}-\mathrm{Y}$ recorder. The calculation of the GC content from the melting temperature was done according to Marmur \& Doty (1962).

The genome size determinations were performed by the renaturation method of Wetmur \& Davidson (1968) with the modifications described by Bak et al. (1969) and Bak, Christiansen \& Stenderup (I970).

\section{RESULTS}

Melting temperatures and base compositions are shown in Table I. The GC contents are found to be between 24.4 and $32.9 \%$, which is within the range known for mycoplasmal DNA. 
Fourteen calculated genome sizes (Table ${ }^{-1}$ ) vary between 4.0 and $5.6 \times 10^{8}$ daltons. The deoxyribonucleic acids from the three remaining strains representing Acholeplasma laidlawii, serogroup 6 of Leach,"and serogroup K of Al-Aubaidi have genome sizes about twice as large $\left(0.99\right.$ to $\mathrm{I} \cdot \mathrm{I} \times 1 \mathrm{I}^{9}$ daltons). It should ${ }^{\top}$ be mentioned that the genome size for $A$. laidlawii is the value determined by Bak et al. (1969).

\section{DISCUSSION}

GC contents of nine of the mycoplasmas studied have been reported previously. Regarding six of these species or subspecies (Mycoplasma dispar, M. mycoides subsp. mycoides, M. mycoides subsp. capri, M. bovigenitalium, M. arginini and Acholeplasma laidlawii) our results are in good agreement with earlier investigations (Neimark \& Pené, 1965; McGee, Rogul \& Wittler, 1967; Morowitz, Bode \& Kirk, I967; Neimark, 1967; Chelton, Jones \& Walker, 1968; Kelton \& Mandel, I969; Williams, Wittler \& Burris, I969; Gourlay \& Leach, I970; Neimark, 1970). Discrepancies were, however, found as regards Mycoplasma bovirhinis and both subspecies of $M$. agalactiae. Using the method of thermal denaturation. Neimark (1967) gave the GC content of $33.6 \%$ for a strain of $M$. agalactiae and Morowitz et al. (1967) found the melting temperature of the DNA of $M$. agalactiae subsp. bovis (strain Donetta) to be $82.8{ }^{\circ} \mathrm{C}$ corresponding to a GC content of $32.9 \%$. In these cases our results are 3 and $5 \%$ lower. With regard to $M$. bovirhinis our result is $2 \%$ higher than the GC content $(25 \%$ \%) given by Williams et al. ( 1969$)$.

Our results do not add further to the current discussion whether PGI and PG3 should be regarded as variants of the same species, Mycoplasma mycoides, or representatives of two distinct species (Edward \& Freundt, I 969). Although their GC contents differ by approximately $3 \%$ this difference does not exclude a high degree of homology between the deoxyribonucleic acids. Similar considerations apply to PG2 and Donetta, the type strains of the two subspecies of $M$. agalactiae.

Electron microscopy of Mycoplasma agalactiae subsp. bovis indicates a genome size of $5.9 \times 10^{8}$ daltons (Morowitz et al. 1967 ), which agrees closely with our determination.

PG49 (serogroup 6 of Leach) and BI07PA (serogroup K of Al-Aubaidi) as well as the type strain of Acholeplasma laidlawii (PG8) were also found to have a genome size characteristic of the Acholeplasmataceae. Only these three strains have been found to be non-sterolrequiring and sensitive to digitonin (Edward, I97I ; Ernø \& Stipkovits, in preparation, so they belong to Acholeplasmataceae. Our results confirm the findings of Bak et al. (I969) that the Acholeplasmataceae have genome sizes in the range of $\mathrm{I} \times \mathrm{IO}^{9}$ daltons, whereas Mycoplasmataceae have genome sizes of about half this size $\left(4^{\circ} 0\right.$ to $5.6 \times 10^{8}$ daltons).

\section{REFERENCES}

Bak, A. L., Black, F. T., Christiansen, C. \& Freundt, E. A. (1969). Genome size of mycoplasmal DNA. Nature, London 224, I 209-I 2 IO.

Bak, A. L., Christiansen, C. \& Stenderup, A. (1970). Bacterial genome sizes determined by DNA renaturation studies. Journal of General Microbiology 64, 377-380.

Bak, A. L. \& Stenderup, A. (1969). Deoxyribonucleic acid homology in yeasts. Genetic relatedness within the genus Candida. Journal of General Microbiology 59, 2 I-30.

Chelton, E. T. J., Jones, A. S. \& Walker, R. T. (I968). The chemical composition of the nucleic acids and the proteins of some Mycoplasma strains. Journal of General Microbiology 50, 305-3I 2.

EDWARD, D. G. FF. (197I). Determination of sterol requirement for Mycoplasmatales. Journal of General Microbiology 69, 205-210. 
Edward, D. G. FF. \& Freundt, E. A. (1969). Classification of the Mycoplasmatales. In The Mycoplasmatales and the L-Phase of Bacteria, pp. 187-190. Edited by L. Hayflick. New York: Appleton-CenturyCrofts.

Edward, D. G. FF. \& Freundt, E. A. (1970). Amended nomenclature for strains related to Mycoplasma laidlawii. Journal of General Microbiology 62, 1-2.

FRIIS, N. F. (1972). Isolation and characterization of a new porcine mycoplasma. Acta veterinaria scandinavica I3, 284-286.

Gourlay, R. N. \& LEACH, R. H. (1970). A new Mycoplasma species isolated from pneumonic lungs of calves (Mycoplasma dispar sp.nov.). Journal of Medical Microbiology 3, I I I-I 23.

Kelton, W. H. \& MANDEl, M. (I969). Deoxyribonucleic acid base compositions of Mycoplasma strains of avian origin. Journal of General Microbiology 56, I3 I-I 35.

LANGFord, E. V. \& Dorward, W. J. (1969). A mycoplasma isolated from cattle with infectious bovine kerato-conjunctivitis. Canadian Journal of Comparative Medicine and Veterinary Science 33, $275_{-279 .}$

McGee, Z. A., Rogul, M. \& Wittler, R. G. (1967). Molecular genetic studies of relationships among mycoplasma, L-forms and bacteria. Annals of the New York Academy of Sciences 143, 21-30.

MARMUR, J. (1961). A procedure for the isolation of deoxyribonucleic acid from microorganisms. Journal of Molecular Biology 3, 208-218.

Marmur, J. \& Doty, P. (1962). Determination of the base composition of deoxyribonucleic acid from its thermal denaturation temperature. Journal of Molecular Biology 5, 109-I 8.

Morowitz, H. J., Bode, H. R. \& KIRK, R. G. (I967). The nucleic acids of Mycoplasma. Annals of the New York Academy of Sciences $143,110-114$.

Neimark, H. (I967). Heterogeneity among the Mycoplasma and relationships to bacteria. Annals of the New York Academy of Sciences 143, 31-37.

Neimark, H. C. (1970). Division of Mycoplasmas into subgroups. Journal of General Microbiology 63, 249-263.

NeIMARK, H. C. \& PENÉ, J. J. (I965). Characterization of pleuropneumonia-like organisms by deoxyribonucleic acid composition. Proceedings of the Society for Experimental Biology and Medicine II8, 5I 7-5I9.

Wetmur, J. G. \& Davidson, N. (1968). Kinetics of renaturation of DNA. Journal of Molecular Biology 3I, 349-370.

Williams, C. O., Wittler, R. G. \& Burris, C. (1969). Deoxyribonucleic acid base compositions of selected Mycoplasmas and L-phase variants. Journal of Bacteriology 99, 34I-343. 